\title{
PERAMALAN KUANTITI PENJUALAN HERBISIDA MENGGUNAKAN METODE SINGLE EXPONENTIAL SMOOTHING STUDI KASUS PT. PETROKIMIA KAYAKU
}

\author{
M. Syaichuddin ${ }^{1}$ ), Soffiana Agustin ${ }^{2}$ ), Umi Chotijah²) \\ ${ }^{1)}$ PT. Petrokimia Kayaku \\ Kawasan Industri Petrokimia Gresik, Jl. Tri Dharma, Randuboyo, Ngipik, Kec. Gresik, Kabupaten Gresik, Jawa \\ Timur 61121 \\ 1) Prodi Teknik Informatika Universitas Muhammadiyah Gresik \\ E-Mail : hashirama.saiku@ gmail.com ${ }^{\mathbf{1}}$ ) \\ ABSTRAK
}

Peluang usaha di sektor pertanian Indonesia cukup besar, salah satunya peluang usaha di bidang pestisida. PT. Pertumbuhan Petrokimia Kayaku di industri pestisida dan bahan kimia pertanian lainnya. Salah satu jenis pestisida yang diproduksi oleh PT. Petrokimia Kayaku adalah salah satu jenis herbisida yang digunakan untuk mengendalikan gulma atau tanaman pembohong yang membalikkan pertumbuhan tanaman pertanian. Jangka waktu penggunaan herbisida sangat bergantung pada faktor musim. Hal ini mempengaruhi jumlah penjualan produk herbisida yang berbeda dari waktu ke waktu kepada perusahaan. Peramalan adalah proses menentukan peristiwa atau kondisi masa depan yang datang berdasarkan data dan pengalaman historis untuk menemukan minat dari pola yang berkaitan dengan masalah tersebut. Dalam penelitian ini, Pengembangan Sistem Informasi Peramalan Penjualan Kuantitatif untuk Herbisida Dikembangkan Dengan Metode Eksponensial Tunggal. Metode tersebut membutuhkan nilai alpha $(\alpha)$ sebagai nilai parameter smoothing. Nilai $\alpha$ yang lebih tinggi diberikan ke data yang lebih baru, sehingga nilai parameter $\alpha$ yang sesuai akan memberikan prediksi yang optimal dengan nilai kesalahan. Nilai $\alpha$ dilakukan dengan membandingkan menggunakan interval pemulusan antara $0<\alpha<1$ yaitu $\alpha$ (0,1 sampai 0,9$)$.

Keywords : Data Mining, Forecasting, Single Exponential Smoothing

\section{PENDAHULUAN}

PT. Petrokimia Kayaku diresmikan pada 30 Juli 1977 sebagai perusahaan yang berstatus Penanaman Modal Asing (PMA) dengan kepemilikan saham PT. Petrokimia Gresik sebanyak 60\%, Mitsubishi Co. sebanyak 20\%, dan Nippon Kayaku sebanyak 20\%. PT. Petrokimia Kayaku berkembang dalam industri pestisida dan bahan kimia pertanian lain. Salah satu jenis pestisida yang diproduksi oleh PT. Petrokimia Kayaku yaitu pestisida jenis herbisida yang difungsikan untuk mengandalikan gulma atau tanaman liar yang mengganggu pertumbuhan tanaman pertanian. Produk herbisida yang paling diminati oleh customer adalah BSM 486SL kemasan 1 liter dan GMQ 282SL kemasan 1 liter yang merupakan herbisida sistemik berbentuk cair. Bagi suatu manajemen perusahaan, penjualan produk herbisida perlu dicermati karena menjadi dasar pengukuran prestasi keuangan perusahaan. Oleh karena itu, untuk menentukan target penjualan yang ingin dicapai dengan memperhatikan kondisi dan keadaan dimasa lampau setiap perusahaan perlu membuat rencana kerja. Dari target penjualan yang ditetapkan kemudian menghasilkan strategi penjualan, pemasaran, dan seterusnya. Awal mula rencana kerja perusahaan yaitu menentukan atau meramalkan kuantiti penjualan pada periode yang akan datang.

Permasalahan yang dialami PT. Petrokimia Kayaku adalah ketika pihak management harus merencanakan dan menyiapkan banyaknya kuantiti herbisida yang dijual dibulan berikutnya berdasarkan perkiraan, sehingga terjadi kesalahan dalam perencanaan penjualan. Peramalan kuantiti penjualan yang terlalu besar atau kurang akurat dapat juga berdampak pada peningkatan biaya yang terkait dengan inventori sehingga investasi yang ditanamkan menjadi tidak efisien. Dengan kata lain, tidak ada perusahaan yang dapat menghindar dari kegiatan meramalkan kuantiti penjualan agar stok / inventori di perusahaan dapat dikendalikan.

Informasi penjualan sangat dibutuhkan untuk membantu merencanakan produksi agar lebih akurat dan stok produk herbisida di perusahaan bisa terkontrol dengan baik. Oleh sebab itu diperlukan suatu sistem yang dapat meramalkan penjualan herbisida dari waktu ke waktu, sehingga dengan hasil peramalan yang diperoleh, management yang berkepentingan diharapkan bisa mengambil keputusan sesuai dengan kondisi yang ada. 
INDEXIA: Informatic and Computational Intelegent Journal

M. Syaichuddin, Soffiana Agustin, UmiChotijah

Peramalan Kuantiti Penjualan Herbisida Menggunakan Metode Single Exponential Smoothing Studi

Kasus Pt. Petrokimia Kayaku

Metode single exponential smoothing merupakan suatu prosedur yang secara terus menerus memperbaiki peramalan dengan merata-rata nilai masa lalu dari suatu data deret waktu dengan cara menurun (eksponensial). Metode ini sangat cocok digunakan untuk meramalkan hal-hal yang fluktuasinya secara acak (tidak teratur). Dengan data perhitungan menggunakan data kuantiti penjualan yang direkap oleh perusahaan dari beberapa periode sebelumnya yang akan digunakan oleh pihak management sebagai bahan dalam membuat perencanaan penjualan herbisida pada PT. Petrokimia Kayaku.

\section{LANDASAN TEORI}

\subsection{Pestisida}

Pestisida adalah substansi kimia (bahan kimia, campuran bahan kimia atau bahan-bahan lain) bersifat racun dan bioaktif yang digunakan untuk membunuh atau mengendalikan berbagai hama, baik insekta, jamur maupun gulma. Pestisida (Inggris = Pesticide) berasal dari kata pest yang berarti organisme pengganggu tanaman (hama) dan cide yang berarti mematikan atau racun. Berikut ini pengertian dan definisi pestisida dari beberapa sumber buku:

1. Menurut USEPA (United States Environmental Protection Agency), pestisida merupakan zat atau campuran yang digunakan untuk mencegah, memusnahkan, menolak, atau memusuhi hama dalam bentuk hewan, tanaman dan mikroorganisme pengganggu (Zulkarnain, 2010).

2. Menurut The United State Federal Environmental Pesticide Control Act, pestisida merupakan suatu zat yang fungsinya untuk memberantas atau mencegah gangguan OPT diantaranya serangga, binatang pengerat, nematoda, cendawan, gulma, virus, bakteri, jasad renik yang dianggap hama pengganggu tanaman (Kardinan, A., 2000).

Berdasarkan pengertian diatas, maka dapat disimpulkan bahwa pestisida adalah bahan beracun yang digunakan untuk membasmi organisme hidup yang mengganggu tanaman, ternak dan sebagainya.

\subsection{Formulasi Pestisida}

Formulasi sangat menentukan bagaimana pestisida dengan bentuk dan komposisi tertentu harus digunakan, berapa dosis atau takaran yang harus digunakan, berapa frekuensi dan interval penggunaan, serta terhadap jasad sasaran apa pestisida dengan formulasi tersebut dapat digunakan secara efektif. Selain itu, formulasi pestisida juga 
INDEXIA: Informatic and Computational Intelegent Journal

M. Syaichuddin, Soffiana Agustin, UmiChotijah

Peramalan Kuantiti Penjualan Herbisida Menggunakan Metode Single Exponential Smoothing Studi

Kasus Pt. Petrokimia Kayaku

EC merupakan formulasi klasik yang paling banyak digunakan saat ini.

2. Water Soluble Concentrate (WCS), merupakan formulasi yang mirip dengan EC, tetapi karena menggunakan sistem solvent berbasis air maka konsentrat ini jika dicampur air tidak membentuk emulsi, melainkan akan membentuk larutan homogen. Umumnya formulasi ini digunakan dengan cara disemprotkan.

3. Aquaeous Solution (AS), merupakan pekatan yang bisa dilarutkan dalam air. Pestisida yang diformulasi dalam bentuk AS umumnya berupa pestisida yang memiliki kelarutan tinggi dalam air. Pestisida yang diformulasi dalam bentuk ini digunakan dengan cara disemprotkan.

4. Soluble Liquid (SL), merupakan pekatan cair. Jika dicampur air, pekatan cair ini akan membentuk larutan. Pestisida ini juga digunakan dengan cara disemprotkan.

5. Ultra Low Volume (ULV), merupakan sediaan khusus untuk penyemprotan dengan volume ultra rendah, yaitu volume semprot antara 1 - 5 liter/hektar. Formulasi ULV umumnya berbasis minyak karena untuk penyemprotan dengan volume ultra rendah digunakan butiran semprot yang sangat halus.

Bentuk formulasi dan kandungan bahan aktif pestisida dicantumkan di belakang nama dagangnya. Adapun prinsip pemberian nama dagang yaitu:

1. Jika diformulasi dalam bentuk padat, angka di belakang nama dagang menunjukkan kandungan bahan aktif dalam persen. Sebagai contoh herbisida Karmex 80 WP mengandung $80 \%$ bahan aktif. Pestisida Furadan 3G berarti mengandung bahan aktif 3\%.

2. Jika diformulasi dalam bentuk cair, angka di belakang nama dagang menunjukkan jumlah gram atau mililiter (ml) bahan aktif untuk setiap liter produk. Sebagai contoh, fungisida Score 250 EC mengandung $250 \mathrm{ml}$ bahan aktif dalam setiap liter produk Score 250 EC.

3. Jika produk tersebut mengandung lebih dari satu macam bahan aktif maka kandungan bahan-bahan aktifnya dicantumkan semua dan dipisahkan dengan garis miring. Sebagai contoh, fungisida Ridomil Gold

MZ 4/64 WP mengandung bahan bahan aktif Metalaksil-M 4\% dan Mankozeb $64 \%$ dan diformulasikan dalam bentuk WP.

\subsection{Jenis Pestisida}

Berdasarkan target sasaran yang dibunuh, pestisida diklasifikasikan menjadi beberapa jenis, yaitu sebagai berikut (Sudarmo \& Subiyakto, 1991):

1. Akarisida, berasal dari kata akari, yang dalam bahasa Yunani berarti tungau atau kutu. Akarisida sering juga disebut Mitesida. Fungsinya untuk membunuh tungau atau kutu. Contohnya Kelthene MF dan Trithion 4 E.

2. Algasida, berasal dari kata alga, bahasa latinnya berarti ganggang laut, berfungsi untuk membunuh algae. Contohnya Dimanin.

3. Alvisida, berasal dari kata avis, bahasa latinnya berarti burung, fungsinya sebagai pembunuh atau penolak burung. Contohnya Avitrol untuk burung kakaktua.

4. Bakterisida, Berasal dari katya latin bacterium, atau kata Yunani bakron, berfungsi untuk membunuh bakteri. Contohnya Agrept, Agrimycin, Bacticin, Tetracyclin, Trichlorophenol Streptomycin.

5. Fungsida, berasal dari kata latin fungus, atau kata Yunani spongos yang artinya jamur, berfungsi untuk membunuh jamur atau cendawan. Dapat bersifat fungitoksik (membunuh cendawan) atau fungistatik (menekan pertumbuhan cendawan). Contohnya Benlate, Dithane M-45 80P, Antracol 70 WP, Cupravit OB 21, Delsene MX 200, Dimatan 50 WP.

6. Herbisida, berasal dari kata lain herba, artinya tanaman setahun, berfungsi untuk membunuh gulma. Contohnya Gramoxone, Basta 200 AS, Basfapon 85 SP, Esteron 45 Pg.

7. Insektisida, berasal dari kata latin insectum, artinya potongan, keratan segmen tubuh, berfungsi untuk membunuh serangga. Contohnya Lebaycid, Lirocide 650 EC, Thiodan, Sevin, Sevidan 70 WP, Tamaron. 
INDEXIA: Informatic and Computational Intelegent Journal

M. Syaichuddin, Soffiana Agustin, UmiChotijah

Peramalan Kuantiti Penjualan Herbisida Menggunakan Metode Single Exponential Smoothing Studi

Kasus Pt. Petrokimia Kayaku

8. Molluskisida, berasal dari kata Yunani molluscus, artinya berselubung tipis atau lembek, berfungsi untuk membunuh siput. Contohnya Morestan, PLP, Brestan 60.

9. Nematisida, berasal dari kata latin nematoda, atau bahasa Yunani nema berarti benang, berfungsi untuk membunuh nematoda. Contohnya Nemacur, Furadan, Basamid G, Temik 10 G, Vydate.

10. Ovisida, berasal dari kata latin ovum berarti telur, berfungsi untuk merusak telur. J. Pedukulisida, berasal dari kata latin pedis, berarti kutu, tuma, berfungsi untuk membunuh kutu atau tuma.

11. Piscisida, berasal dari kata Yunani Piscis, berarti ikan, berfungsi untuk membunuh ikan. Contohnya Sqousin untuk Cypirinidae, Chemish 5 EC.

12. Predisida, berasal dari kata Yunani Praeda berarti pemangsa, berfungsi sebagai pembunuh predator.

13. Rodentisida, berasal dari kata Yunani rodere, berarti pengerat berfungsi untuk membunuh binatang pengerat. Contohnya Dipachin 110, Klerat RMB, Racumin, Ratikus RB, Ratilan, Ratak, Gisorin. N.

14. Termisida, berasal dari kata Yunani termes, artinya serangga pelubang kayu berfungsi untuk membunuh rayap. Contohnya Agrolene $26 \mathrm{WP}$, Chlordane 960 EC, Sevidol 20/20 WP, Lindamul 10 EC, Difusol CB.

15. Silvisida, berasal dari kata latin silva berarti hutan, berfungsi untuk membunuh pohon atau pembersih pohon.

16. Larvasida, berasal dari kata Yunani lar, berfungsi membunuh ulat (larva). Contohnya Fenthion, Dipel (Thuricide).

\subsection{Herbisida}

Penyiang gulma atau herbisida adalah bahan kimia yang dapat menghambat pertumbuhan atau mematikan tumbuhan. Herbisida mempengaruhi proses pembelahan sel, perkembangan jaringan, pembentukan klorofil, respirasi, fotosintesis, metabolisme, nitrogen, aktivitas enzim dan sebagainya. Herbisida sangat diperlukan tumbuhan untuk mempertahankan kelangsungan hidupnya (Dad R. J., S., 2010). Herbisida berasal dari senyawa kimia organik maupun anorganik atau berasal dari

metabolit hasil ekstraksi dari suatu organisme. Herbisida bersifat racun terhadap gulma atau tumbuhan pengganggu, juga terhadap tanaman. Herbisida yang diaplikasikan dengan dosis tinggi akan mematikan seluruh bagian tumbuhan. Namun pada dosis yang lebih rendah, herbisida akan membunuh tumbuhan tertentu dan tidak merusak tumbuhan yang lainnya.

1. Secara umum herbisida dapat dibagi dalam dua golongan, yaitu herbisida kontak dan sistemik (Dad R. J., S., 2010).

2. Herbisida kontak mengendalikan gulma dengan cara mematikan bagian gulma yang terkena langsung dengan herbisida. Sifat herbisida ini tidak ditranslokasikan atau tidak dialirkan dalam tubuh gulma. Jika banyak organ gulma yang terkena herbisida, maka semakin baik juga daya kerja herbisida. Contoh herbisida kontak yang berisifat selektif yaitu oksifluorfen, oksadiazon dan propanil, serta sebagian herbisida lainnya bersifat tidak selektif seperti parakuat dan glufosinat.

3. Herbisida Sistemik adalah herbisida yang dialirkan dari tempat terjadinya kontak pertama dengan herbisida ke bagian lainnya, biasanya akan menuju pada titik tumbuh karena pada bagian tersebut metabolisme tumbuhan paling aktif berlangsung. Herbisida jenis ini dapat diaplikasikan melalui tajuk maupun melalui tanah. Contoh herbisida yang melalui tajuk yaitu herbisida glifosat, sulfosat dan ester. Contoh herbisida yang melalui tanah yaitu herbisida ametrin, atrazin, metribuzin dan diuron.

\subsection{Produk Herbisida PT. Petrokimia Kayaku}

Produk herbisida pada PT. Petrokimia kayaku yang paling diminati adalah BSM 486SL 1 liter dan GMQ 282SL 1 liter, berikut adalah penjelasan tentang produk tersebut :

1. BSM 486SL 1 liter, merupakan Herbisida sistemik purna tumbuh yang berbahan dasar glyphosate, berbentuk larutan dalam air berwarna kuning untuk mengendalikan gulma pada hutan tanaman industri Acacia mangium, pertanaman kakao TBM (Tanaman Berbuah Muda), pertanaman karet (TBM), pertanaman kelapa sawit (TBM), pertanaman kopi (TBM), lahan 
INDEXIA: Informatic and Computational Intelegent Journal

M. Syaichuddin, Soffiana Agustin, UmiChotijah

Peramalan Kuantiti Penjualan Herbisida Menggunakan Metode Single Exponential Smoothing Studi

Kasus Pt. Petrokimia Kayaku

tanpa tanaman, padi sawah TOT (Tanpa

Olah Tanah) dan teh.

2. GMQ 282SL 1 liter, merupakan Herbisida racun kontak purna tumbuh berbahan dasar glyphosate berbentuk larutan dalam air berwarna hijau tua untuk mengendalikan gulma pertanaman karet (TBM), pertanaman kelapa sawit (TBM), lahan tanpa tanaman, persiapan lahan kedelai TOT, persiapan lahan padi pasang surut TOT, persiapan lahan jagubng TOT, kopi, teh dan hutan tanaman akasia.

\subsection{Aplikasi}

Aplikasi merupakan suatu subkelas perangkat lunak komputer yang memanfaatkan kemampuan komputer langsung untuk melakukan suatu tugas yang diinginkan pengguna. Biasanya dibandingkan dengan perangkat lunak sistem yang mengintegrasikan berbagai kemampuan komputer.

Terdapat beberapa teori yang mendefinisikan Aplikasi yang dikemukakan oleh beberapa para ahli, diantaranya adalah :

a) Menurut (Febrian, J., \& Andayani, F., 2007) dalam buku kamus yang berjudul komputer dan teknologi informasi Aplikasi adalah program siap pakai, program yang direka untuk melaksanakan suatu fungsi bagi pengguna atau aplikasi yang lain.

b) Menurut (Sutarman, 2009 : 147) dalam bukunya yang berjudul pengantar teknologi, aplikasi merupakan program-program yang dibuat oleh suatu perusahaan komputer untuk para pemakai yang beroperasi dalam bidang umum, seperti pertokoan, komunikasi, penerbangan, perdagangan dan sebagainya.

c) Menurut (Hendrayudi, 2009 : 143) Aplikasi adalah kumpulan perintah program yang dibuat untuk melakukan pekerjaan-pekerjaan tertentu (khusus).

\subsection{Penjualan}

\subsubsection{Pengertian Penjualan}

Penjualan merupakan pembelian suatu (barang atau jasa) dari suatu pihak kepada pihak lainnya dengan mendapatkan ganti uang dari pihak tersebut. Penjualan juga merupakan suatu sumber pendapatan perusahaan, semakin besar penjualan maka semakan besar pula pendapatan yang diperoleh perusahaan. Menurut (Simamora, H., 2000 : 24), penjualan adalah pendapatan lazim dalam perusahaan dan merupakan jumlah kotor yang dibebankan pelanggan atas barang dan jasa. Menurut (Marom, C., 2002 : 28),

menyatakan bahwa penjualan adalah penjualan barang dagangan sebagai usaha pokok perusahaan yang biasanya dilakukan secara teratur.

Berdasarkan pengertian diatas, maka dapat disimpulkan bahwa penjualan adalah persetujuan kedua belah pihak antara penjual dan pembeli, dimana penjual menawarkan sebuah produk dengan harapan pembeli dapat menyerahkan sejumlah uang sebagai alat ukur produk tersebut sebesar harga jual yang telah disepakati.

\subsubsection{Tujuan Penjualan}

Dalam suatu perusahaan kegiatan penjualan adalah kegiatan yang penting karena dengan adanya kegiatan penjualan tersebut maka akan terbentuk laba yang dapat menjamin kelangsungan hidup perusahaan.

Tujuan umum penjualan yang dimiliki oleh suatu perusahaan menurut (Swastha, B., $2005:$ 404) yaitu

1) Mencapai volume penjualan tertentu.

2) Mendapat laba tertentu.

3) Menunjang pertumbuhan perusahaan.

Berdasarkan uraian diatas dapat disimpulkan bahwa tujuan umum perusahaan dalam kegiatan penjualan adalah untuk mencapai volume penjualan, mendapat laba yang maksimal dengan modal sekecil-kecilnya, dan menunjang pertumbuhan suatu perusahaan.

\subsubsection{Faktor Yang Mempengaruhi Penjualan}

Aktivitas penjualan banyak dipengaruhi oleh faktor tertentu yang dapat meningkatkan aktivitas perusahaan. Oleh karena itu manajer penjualan perlu memperhatikan faktor-faktor yang mempengaruhi penjualan. Menurut Basu Swastha (2005 : 406) Faktor-faktor yang mempengaruhi penjualan adalah sebagai berikut :

1) Kondisi dan kemampuan penjual.

2) Kondisi Pasar.

3) Modal.

4) Kondisi organisasi perusahaan.

5) Faktor-faktor lain.

Menurut pengertian diatas dapat diuraikan sebagai berikut :

1) Kondisi dan kemampuan penjual

Kondisi dan kemampuan terdiri dari pemahaman atas beberapa masalah penting yang berkaitan dengan produk yang dijual, jumlah dan sifat dari tenaga penjual adalah :

a) Jenis dan karakteristik barang atau jasa yang ditawarkan.

b) Harga produk dan jasa. 
INDEXIA: Informatic and Computational Intelegent Journal

M. Syaichuddin, Soffiana Agustin, UmiChotijah

Peramalan Kuantiti Penjualan Herbisida Menggunakan Metode Single Exponential Smoothing Studi

Kasus Pt. Petrokimia Kayaku

c) Syarat penjualan seperti pembayaran dan pengiriman.

2) Kondisi Pasar

Pasar sebagai kelompok pembelian atau pihak yang menjadi sasaran dalam penjualan dan dapat pula mempengaruhi kegiatan penjualannya.

3) Modal

Modal atau dana sangat diperlukan dalam rangka untuk mengangkut barang dagangan ditempatkan atau untuk membesar usahanya.

4) Kondisi Organisasi Perusahaan

Pada perusahan yang besar, biasanya masalah penjual ini ditangani oleh bagian tersendiri, yaitu bagian penjualan yang dipegang oleh orang-orang yang ahli dibidang penjualan.

5) Faktor-faktor Lain

Faktor-faktor lain seperti periklanan, peragaan, kampanye, dan pemberian hadiah sering mempengaruhi penjualan karena diharapkan dengan adanya faktor-faktor tersebut pembeli akan kembali membeli lagi barang yang sama.

Berdasarkan uraian diatas dapat disimpulkan bahwa ada beberapa faktor yang mempengaruhi kegiatan penjualan yaitu kondisi dan kemampuan penjualan, kondisi pasar, modal, kondisi organisasi perusahaan dan faktor-faktor lain.

\subsection{Peramalan}

\subsubsection{Pengertian Peramalan}

Prakiraan pada dasarnya merupakan suatu dugaan atau prediksi mengenai terjadinya suatu kejadian atau peristiwa di masa yang akan datang. Prakiraan dapat disebut juga dengan peramalan yang ilmiah (educated guess). Setiap pengambilan keputusan yang menyangkut keadaan di masa yang akan datang, maka pasti ada prakiraan yang melandasi pengambilan keputusan tersebut ( Assauri, S., 1984).

Dengan kata lain, peramalan adalah proses untuk menduga kejadian atau kondisi di masa mendatang berdasarkan data historis dan pengalaman untuk menemukan kecenderungan dari pola sistematis yang bertujuan memperkecil resiko kesalahan. Peramalan dibutuhkan karena semua industri beroperasi dalam lingkungan yang tidak jelas tetapi keputusan yang dibuat hari ini akan mempengaruhi masa depan institusi/industri. Peramalan yang efektif sangat dibutuhkan untuk mencapai tujuan strategis dan operasional dari semua institusi/industri.

\subsubsection{Tujuan Peramalan}

Dalam dunia usaha penting diperkirakan hal hal yang terjadi di masa depan sebagai dasar untuk pengambilan keputusan, terutama dunia usaha itu merupakan bagian dari kehidupan sosial, di mana segala sesuatu yang terjadi serba tidak pasti, sukar diprediksi dengan cepat. Oleh karena itu perlu dilakukan sebuah peramalan / rencana. Peramalan yang dibuat selalu diupayakan agar dapat :

1. Meminimalkan pengaruh ketidakpastian terhadap perusahaan.

2. Menurut (Gasperz, V., 2005 : 75) tujuan peramalan adalah untuk meramalkan permintaan dan item - item independent demand di masa yang akan datang, sedangkan menurut (Subagyo, P., 2002 : 1) tujuan peramalan adalah mendapatkan peramalan yang bisa meminimalkan kesalahan meramal (Forecast Error) yang bisa diukur dengan Mean Absolute Error (MAE) dan Mean Square Error (MSE).

Dengan adanya peramalan penjualan ini berarti manajemen perusahaan telah mendapatkan gambaran gambaran tentang penjualan dimasa yang akan datang, sehingga manajemen perusahaan akan memperoleh masukan secara objektif dalam menentukan kebijakan perusahaan.

\subsubsection{Tahap-Tahap Peramalan}

Menurut (Gasperz, V., 2005) ada sembilan langkah yang harus diperhatikan yang digunakan untuk menjamin efektifitas dan efisiensi dari sistem peramalan sebagai berikut :

1. Menentukan tujuan dari peramalan.

2. Memilih item yang akan diramalkan.

3. Menentukan horizon waktu peramalan.

4. Memilih model - model peramalan.

5. Memperoleh data yang dibutuhkan untuk melakukan peramalan.

6. Validasi model peramalan.

7. Membuat peramalan.

8. Implementasikan hasil - hasil peramalan.

9. Memantau keandalan hasil peramalan.

(Murahartawaty, 2009) Dalam prakiraan atau peramalan, jangka waktu peramalan dibagi menjadi 3, yaitu :

a. Prakiraan jangka pendek (short term forecasting), yaitu prakiraan yang dilakukan untuk penyusunan hasil prakiraan yang jangka waktunya harian hingga setiap jam.

b. Prakiraan jangka menengah (mid term forecasting), yaitu prakiraan yang dilakukan 
INDEXIA: Informatic and Computational Intelegent Journal

M. Syaichuddin, Soffiana Agustin, UmiChotijah

Peramalan Kuantiti Penjualan Herbisida Menggunakan Metode Single Exponential Smoothing Studi

Kasus Pt. Petrokimia Kayaku

untuk penyusunan hasil prakiraan yang jangka waktunya mingguan hingga bulanan.

c. Prakiraan jangka panjang (long term forecasting), yaitu prakiraan yang dilakukan untuk penyusunan hasil prakiraan yang jangka waktunya 10 tahunan atau beberapa tahun kedepan.

\subsection{Exponential Smoothing}

\subsubsection{Pengertian Exponential Smoothing}

Metode exponential smoothing merupakan metode peramalan yang cukup baik untuk peramalan jangka panjang dan jangka menengah, terutama pada tingkat operasional suatu perusahaan, dalam perkembangan dasar matematis dari metode smoothing (Winkler, R., \& Makridakis, S., 1983) dapat dilihat bahwa konsep exponential telah berkembang dan menjadi metode praktis dengan penggunaan yang cukup luas, terutama dalam peramalan bagi persedian.

Kelebihan utama dari metode exponential smoothing adalah dilihat dari kemudahan dalam operasi yang relative rendah, ada sedikit keraguan apakah ketepatan yang lebih baik selalu dapat dicapai dengan menggunakan (QS) Quantitatif sistem ataukah metode dekonposisi yang secara intuitif menarik, namun dalam hal ini jika diperlukan peramalan untuk ratusan item.

Menurut (Makridakis, Wheelwright, S., \& McGee., 1983). Menyatakan bahwa apabila data yang dianalisa bersifat stationer, maka penggunaan metode rata-rata bergerak (moving average) atau single exponential smoothing cukup tepat akan tetapi apabila datanya menunjukan suatu trend linier, maka model yang baik untuk digunakan adalah exponential smoothing linier dari brown atau model exponential smoothing linier dari holt.

\subsection{Single Exponential Smoothing}

Pola data yang tidak stabil atau perubahannya besar dan bergejolak umumnya menggunakan model pemulusan eksponensial (Exponential Smoothing Models). Metode Single Exponential Smoothing lebih cocok digunakan untuk meramalkan hal-hal yang fluktuasinya secara acak (tidak teratur). Peramalan menggunakan model pemulusan eksponensial rumusnya adalah sebagai berikut :

$\mathrm{Ft}+1=\alpha \mathrm{Xt}+(1-\alpha) \mathrm{Ft}-1$

Keterangan :

$\mathrm{Ft}+1=$ Ramalan untuk periode ke $\mathrm{t}+1$

$\mathrm{Xt}=$ Nilai riil periode ke $\mathrm{t}$

$\alpha=$ Bobot yang menunjukkan konstanta penghalus $(0<\alpha<1)$

Ft-1 = Ramalan untuk periode ke $\mathrm{t}-1$

Metode ini membutuhkan nilai alpha $(\alpha)$ sebagai nilai parameter pemulusan. Bobot nilai $\alpha$ lebih tinggi diberikan kepada data yang lebih baru, sehingga nilai parameter $\alpha$ yang sesuai akan memberikan ramalan yang optimal dengan nilai kesalahan (error) terkecil. Untuk mendapatkan nilai $\alpha$ yang tepat pada umumnya dilakukan dengan trial and error (cobacoba) untuk menentukan nilai kesalahan terendah. Nilai $\alpha$ dilakukan dengan membandingkan menggunakan interval pemulusan antar $0<\alpha<1$, yaitu $\alpha(0,1$ sampai dengan 0,9$)$. Metode ini hanya mampu memberikan ramalan satu periode ke depan dan cocok untuk data yang mengandung unsur stationer. Karena jika diterapkan pada serial data yang memiliki trend yang konsisten, ramalan yang dibuat akan selalu berada dibelakang trend. Selain itu, metode eksponensial ini juga memberikan bobot yang relatif lebih tinggi pada nilai pengamatan terbaru dibanding nilai-nilai periode sebelumnya.

Akurasi keseluruhan dari setiap model peramalan dapat dijelaskan dengan membandingkan nilai yang diramal dengan nilai aktual atau nilai yang sedang diamati. Jika Ft melambangkan peramalan pada periode $\mathrm{t}$, dan Xt melambangkan permintaan aktual pada periode $t$, maka kesalahan peramalannya (deviasinya) adalah sebagai berikut :

Kesalahan peramalan $=$ Permintaan aktual - Nilai

Peramalan

$=\mathrm{Xt}-\mathrm{Ft}$

Ada beberapa perhitungan yang bisa digunakan untuk menghitung kesalahan peramalan total. Perhitungan ini dapat digunakan untuk membandingkan model peramalan yang berbeda, mengawasi peramalan, dan untuk memastikan peramalan berjalan dengan baik. Tiga dari perhitungan yang paling terkenal adalah error mutlak rata-rata (Mean Absolute Error - MAE), kesalahan kuadrat rata-rata (Mean Squared Error-MSE), dan kesalahan persen mutlak rata-rata (Mean Absolute Percent-MAPE).

Mean Squared Error (MSE) adalah metode lain untuk mengevaluasi metode peramalan. Masingmasing kesalahan atau sisa dikuadratkan. Kemudian dijumlahkan dan dibagi dengan jumlah observasi. Pendekatan ini mengatur kesalahan peramalan yang besar karena kesalahan-kesalahan itu dikuadratkan. Suatu teknik yang menghasilkan kesalahan moderat mungkin lebih baik untuk salah satu yang memiliki 
INDEXIA: Informatic and Computational Intelegent Journal

M. Syaichuddin, Soffiana Agustin, UmiChotijah

Peramalan Kuantiti Penjualan Herbisida Menggunakan Metode Single Exponential Smoothing Studi

Kasus Pt. Petrokimia Kayaku

kesalahan kecil tapi kadang-kadang menghasilkan sesuatu yang sangat besar. Berikut ini rumus untuk menghitung MSE:

$$
\operatorname{MSE}=\frac{1}{n} \sum_{t=1}^{n}\left(X_{t}-F_{t}\right)^{2} .
$$

Keterangan :

$$
\begin{array}{ll}
\mathrm{Ft} & =\text { Nilai ramalan } \\
\mathrm{Xt} & =\text { Nilai Aktual } \\
\mathrm{n} & =\text { Jumlah data error }
\end{array}
$$

Pada kenyataannya tidak ada prediksi yang memiliki tingkat akurasi $100 \%$, karena setiap prediksi pasti mengandung kesalahan. Mean Absolute Error (MAE) yaitu rata-rata nilai absolute error dari kesalahan meramal. Untuk mengetahui metode prediksi dengan tingkat akurasi yang tinggi, maka dibutuhkan menghitung tingkat kesalahan dalam suatu prediksi, semakin kecil tingkat kesalahan yang dihasilkan, maka semakin baik prediksi tersebut. Standar umum pengukuran kesalahan prediksi yang digunakan adalah mean absolute error (MAE) untuk akurasi, dan mean absolute percentage error (MAPE) untuk persentase akurasi.

$$
\text { MAE }=\frac{1}{n} \sum_{t=1}^{n}\left|X_{t}-F_{t}\right|
$$

Keterangan :

$$
\begin{array}{ll}
\mathrm{Ft} & =\text { Nilai ramalan } \\
\mathrm{Xt} & =\text { Nilai Aktual } \\
\mathrm{n} & =\text { Jumlah data error }
\end{array}
$$

Mean Absolute Percantage Error (MAPE) dihitung dengan menggunakan kesalahan absolut dari tiap periode dibagi dengan nilai observasi yang nyata untuk periode itu. Kemudian merata-rata kesalahan persentase absolut tersebut. Pendekatan ini berguna ketika ukuran atau besar variabel ramalan itu penting dalam mengevaluasi ketepatan ramalan. MAPE dapat dihitung dengan rumussebagai berikut.

$$
\text { MAPE }=\frac{1}{n} \sum_{t=1}^{n} \frac{\left|X_{t}-F_{t}\right|}{x_{t}} \times 100 .
$$

Keterangan :

$$
\begin{array}{ll}
\mathrm{Ft} & =\text { Nilai ramalan } \\
\mathrm{Xt} & =\text { Nilai Aktual } \\
\mathrm{n} & =\text { Jumlah data error }
\end{array}
$$

\section{PERANCANGAN SISTEM}

\subsection{Analisis Sistem}

Analisis sistem dilakukan untuk mempelajari dan menganalisa kebutuhan sistem yang akan dibuat sehingga dapat dilakukan perancangan sistem dengan kriteria dan perangkat-perangkat yang ditentukan. Analisis sistem bertujuan untuk mengklasifikasi permasalahan-permasalahan yang ada pada sistem dimana aplikasi dibangun meliputi perangkat lunak

(software), pengguna (user) serta hasil analisis terhadap sistem dan elemen-elemen yang terkait. Analisis ini diperlukan sebagai dasar bagi tahapan perancangan sistem.

PT. Petrokimia Kayaku merupakan salah satu Perusahaan yang bergerak di sektor agrokimia yang menghasilkan produk utama berupa pestisida, pupuk hayati, probiotik ternak dan sejumlah produk lain. BSM 486SL 1 liter dan GMQ 282SL 1 liter yang merupakan 2 dari total 76 produk berjenis herbisida yang paling diminati oleh customer. BSM 486SL 1 liter merupakan jenis herbisida sistemik yang cara kerjanya dengan mengganggu enzim yang berperan dalam membentuk asam amino yang dibutuhakan tanaman, dan mudah menyerap ke seluruh jaringan tanaman, gulma akan mati sampai akar-akarnya. Sedangkan GMQ 282SL 1 liter merupakan jenis herbisida kontak yang berguna untuk menyiang gulma dengan cara langsung mengganggu tanaman untuk berfotositensis, gulma yang secara langsung terkena herbisida kontak akan mati.

Berdasarkan hasil penelitian yang dilakukan pada PT. Petrokimia Kayaku, setiap akhir bulan perusahaan selalu mengadakan meeting dan evaluasi penjualan yang dilakukan oleh divisi penjualan, pengadaan dan produksi. Dari kegiatan tersebut akan menghasilkan rencana kerja. Rencana kerja digunakan untuk menentukan jumlah penjualan yang ingin dicapai satu bulan ke depan. Dari jumlah penjualan yang ditetapkan kemudian melahirkan strategi penjualan, pemasaran dan seterusnya. Titik awal dari penentuan rencana kerja, seperti yang dijelaskan di awal adalah penentuan jumlah kuantiti penjualan.

Mengingat pentingnya mengetahui tingkat penjualan herbisida untuk dapat menentukan persediaan obat selama satu periode, PT. Petrokimia Kayaku memerlukan suatu sistem yang dapat meramalkan tingkat penjualan yang akan terjadi pada bulan yang akan datang, dengan melihat data kuantiti penjualan pada bulan-bulan sebelumnya. Data yang digunakan adalah data kuantiti penjualan BSM 486SL 1 liter dan GMQ 282SL 1 liter dari bulan januari 2015 sampai desember 2017. Selama ini PT. Petrokimia Kayaku dalam menentukan kuantiti penjualan herbisida ke depan tidak obyektif karena berdasarkan intuisi management saja. Dalam menentukan kuantiti penjualan herbisida masih berdasarkan perkiraan, sehingga terjadi kesalahan dalam perencanaan produksi yang berdampak pada proses pendistribusian karena membuat 
INDEXIA: Informatic and Computational Intelegent Journal

M. Syaichuddin, Soffiana Agustin, UmiChotijah

Peramalan Kuantiti Penjualan Herbisida Menggunakan Metode Single Exponential Smoothing Studi

Kasus Pt. Petrokimia Kayaku

ketidakpastian management dalam memproduksi produk herbisida. Jumlah penjualan sering kali tidak sesuai dengan data penjualan aktual yang mempengaruhi perencanaan selanjutnya. Jika produksi herbisida terlalu banyak sedangkan permintaan pasar menurun maka pihak PT. Petrokimia Kayaku akan mengalami kerugian.

\subsection{Hasil Analisa}

Metode Single Exponential Smoothing merupakan salah satu metode yang dapat digunakan untuk mengatasi permasalahan pada PT. Petrokimia Kayaku, dikarenakan metode ini dapat digunakan untuk meramalkan suatu peramalan dengan pola data yang menunjukan suatu trend dan juga musiman.

Sistem peramalan kuantiti penjualan herbisida menggunakan metode Single Exponential Smoothing merupakan suatu sistem yang dikhususkan untuk penentuan jumlah penjualan produk herbisida satu bulan kedepan. Sistem menerima masukan berupa data kuantiti penjualan herbisida yang berisi jumlah produk herbisida dalam satuan botol yang terjual per bulan. Kemudian data tersebut diproses dengan metode Single Exponential Smoothing untuk menghasilkan peramalan bulan depan. Data yang digunakan berupa 2 data produk herbisida yaitu BSM 486SL 1 liter dan GMQ 282SL 1 liter, dimana hasil output dari sistem adalah prediksi atau peramalan penjualan tiap produk herbisida.

Diagram alir analisis sistem peramalan kuantiti penjualan herbisida pada PT. Petrokimia Kayaku di tunjukkan pada gambar berikut:

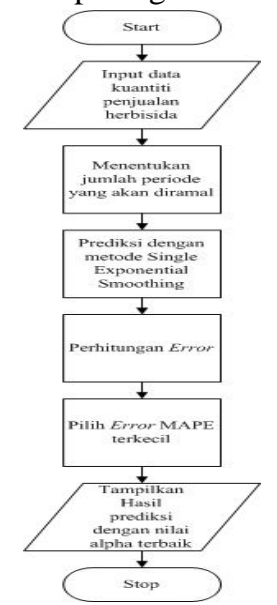

Gambar 3.1 Rancangan Alur Sistem Yang Dibangun

Gambar 3.1 menjelaskan tahap analisis yang dimulai dengan memasukkan data - data dari bulan sebelumnya. Kemudian sistem akan memulai

prediksi hasil produksi periode berikutnya menggunakan metode Single Exponential Smoothing. Setelah proses peramalan selesai maka sistem akan menampilkan hasil peramalan untuk periode berikutnya dengan nilai alpha yang terbaik.

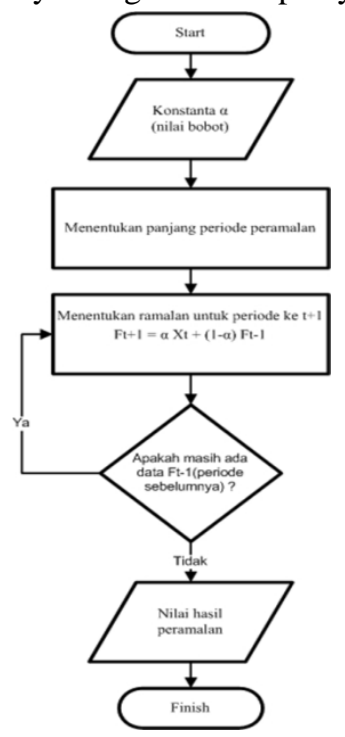

Gambar 3.2 Diagram Alir Metode Single Exponential Smoothing

Keterangan diagram alir metode Single Exponential Smoothing :

1. Nilai bobot $(\alpha)$ akan secara otomatis terisi oleh sistem, yang nantinya akan digunakan untuk nilai pemulusan.

2. Menentukan jumlah periode sebagai dasar proses selanjutnya yaitu menentukan peramalan.

3. Kemudian perhitungan diteruskan dengan menentukan nilai ramalan dengan persamaan 2.1

4. Perulangan jika masih ada periode sebelumnya maka lanjutkan perhitungan dan jika proses perhitungan selesai maka tampilkan hasil peramalan di periode selanjutnya

\subsection{Representasi Model}

Data penjualan merupakan data yang wajib ada dalam proses peramalan atau prediksi, oleh karena itu dalam sistem peramalan ini akan menggunakan data aktual penjualan herbisida 3 tahun terakhir pada PT. Petrokimia Kayaku berdasarkan penelitian sebelumnya. Berikut adalah representasi data aktual penjualan herbesida dan contoh perhitungan penerapan peramalan menggunakan metode Single Exponential Smoothing.

Sumber data yang digunakan adalah total penjualan perbulan dari periode Januari 2015 - Desember 2017. 
INDEXIA: Informatic and Computational Intelegent Journal

M. Syaichuddin, Soffiana Agustin, UmiChotijah

Peramalan Kuantiti Penjualan Herbisida Menggunakan Metode Single Exponential Smoothing Studi

Kasus Pt. Petrokimia Kayaku

Tabel 3.1 dibawah ini menampilkan jumlah penjualan produk herbisida .

Tabel 3.1 Data Penjualan Herbisida Dalam Satuan Botol

\begin{tabular}{|c|c|c|}
\hline Periode & BSM 486SL 1L & GMQ 282SL 1L \\
\hline Jan-2015 & 206480 & 218000 \\
\hline Feb-2015 & 177440 & 199100 \\
\hline Mar-2015 & 215020 & 190000 \\
\hline Apr-2015 & 181800 & 167220 \\
\hline Mei-2015 & 176800 & 179100 \\
\hline Jun-2015 & 207000 & 148180 \\
\hline Jul-2015 & 187000 & 151000 \\
\hline Ags-2015 & 193560 & 148660 \\
\hline Sep-2015 & 220000 & 127160 \\
\hline Okt-2015 & 190020 & 146180 \\
\hline Nov-2015 & 178120 & 152220 \\
\hline Des-2015 & 200500 & 180160 \\
\hline Jan-2016 & 194600 & 200600 \\
\hline Feb-2016 & 183360 & 198700 \\
\hline Mar-2016 & 174560 & 183280 \\
\hline Apr-2016 & 184700 & 170020 \\
\hline Mei-2016 & 211420 & 160580 \\
\hline Jun-2016 & 175860 & 188200 \\
\hline Jul-2016 & 198920 & 181090 \\
\hline Ags-2016 & 187340 & 156660 \\
\hline Sep-2016 & 190000 & 197740 \\
\hline Okt-2016 & 199800 & 183080 \\
\hline Nov-2016 & 218280 & 166660 \\
\hline Des-2016 & 228120 & 190000 \\
\hline Jan-2017 & 182500 & 212000 \\
\hline Feb-2017 & 207900 & 190040 \\
\hline Mar-2017 & 177760 & 177120 \\
\hline Apr-2017 & 215000 & 182000 \\
\hline Mei-2017 & 177560 & 178800 \\
\hline Jun-2017 & 191000 & 210000 \\
\hline Jul-2017 & 208000 & 186700 \\
\hline Ags-2017 & 212980 & 181700 \\
\hline Sep-2017 & 234800 & 166600 \\
\hline Okt-2017 & 176080 & 171000 \\
\hline Nov-2017 & 200620 & 168180 \\
\hline Des-2017 & 185580 & 157080 \\
\hline
\end{tabular}

Pada tabel diatas adalah data aktual penjualan PT. Petrokimia Kayaku selama 3 tahun, dan berikut algoritma perhitungan peramalan dan contoh perhitungan peramalan menggunakan metode Single Exponential Smoothing secara manual. 
INDEXIA: Informatic and Computational Intelegent Journal

M. Syaichuddin, Soffiana Agustin, UmiChotijah

Peramalan Kuantiti Penjualan Herbisida Menggunakan Metode Single Exponential Smoothing Studi

Kasus Pt. Petrokimia Kayaku

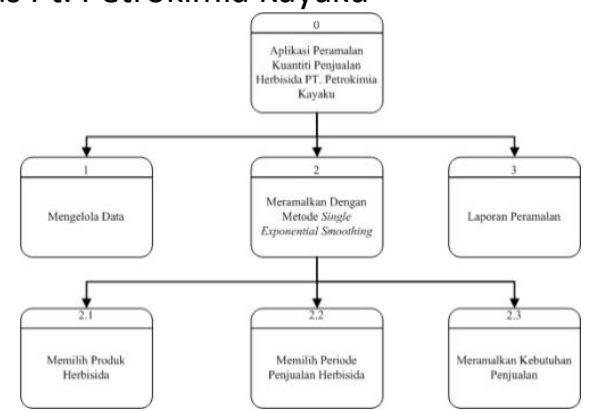

Gambar 3.4 Diagram Berjenjang

1) Top Level : Aplikasi peramalan kuantiti penjualan Herbisida pada PT.

Petrokimia Kayaku

2) Level 0

1. Pengelolaan Data

2. Meramalkan dengan metode Single Exponential Smoothing

3. Laporan hasil peramalan

3) Level 1 :

1.1 Memilih produk

1.2 Memilih periode penjualan

1.3 Meramalkan kebutuhan penjualan periode berikutnya

\subsection{DFD Level 0}

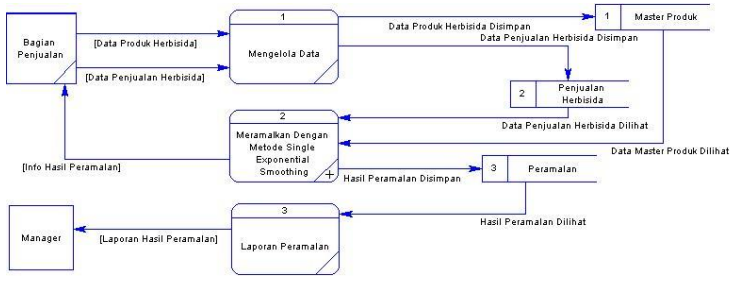

Gambar 3.5 DFD Level 0

Pada Gambar 3.5 diatas dapat dijelaskan sebagai berikut :

a) Proses 1 adalah proses manajemen data yang diinputkan bagian penjualan. Data yang diinputkan merupakan data master produk serta data kuantiti penjualan herbisida perbulan, dimana data tersebut selajutnya digunakan untuk peramalan pada bulan berikutnya.

b) Proses 2 adalah proses penghitungan Single Exponential Smoothing yaitu proses penghitungan peramalan kuantiti penjualan herbisida per periode yang sudah diinputkan sebelumnya beserta perhitungan error MSE, MAE dan MAPE.

Proses 3 adalah proses pembuatan laporan yaitu proses memberikan laporan dari hasil peramalan yang telah dilakukan kepada manajer.

\subsection{DFD Level 1}

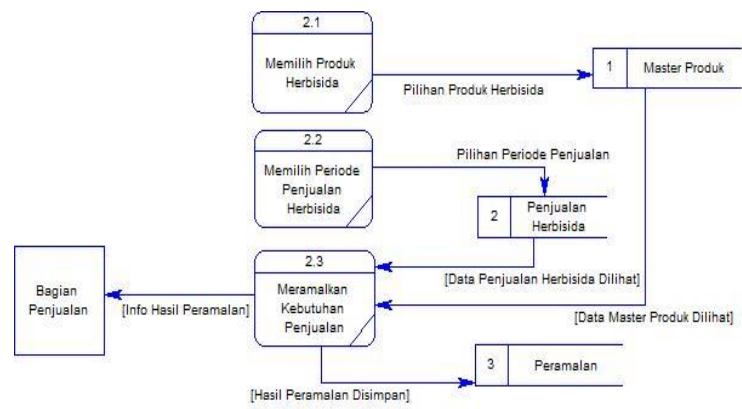

Gambar 3.6 DFD Level 1

Penjelasan DFD Level 1

Pada Gambar 3.6 diatas dapat dijalaskan sebagai berikut :

a) Proses 2.1 adalah langkah pertama untuk memilih produk herbisida yang akan diramalkan kuantiti penjualannya.

b) Proses 2.2 adalah langkah kedua untuk menentukan periode peramalan penujalan.

c) Proses 2.3 adalah langkah ketiga untuk meramalkan nilai pada periode yang akan diramalkan tingkat penjualannya serta menentukan nilai alpha dengan tingkat error terkecil untuk ditampilkan.

\subsection{Skenario Pengujian Sistem}

Skenario pengujian sistem ini akan dilakukan menggunakan data penjualan 3 tahun (Januari 2015 Desember 2017), Kemudian hasil peramalan tersebut akan dibandingkan untuk mendapatkan foreceast error terkecil. Pada skenario pengujian sistem dilakukan dengan cara menghitung penjualan keseluruhan periode bulan pada 2 produk herbisida yaitu BSM 486SL 1 liter dan GMQ 282SL 1 liter, kemudian hasil dari peramalan digunakan untuk acuan menghitung nilai error.

Pengujian pertama data yang diinputkan adalah 36 data penjualan setiap produknya dari seluruh periode data sampel yang terdiri dari 2 jenis produk herbisida yaitu BSM 486SL 1 liter dan GMQ 282SL 1 liter dimana dari 36 data tersebut digunakan sebagai data uji peramalan, dalam sistem peramalan ini dapat meramalkan data penjualan herbisida dibulan berikutnya dari hasil penjualan herbisida secara 3 bulan, 6 bulan, 12 bulan, 24 bulan dan 36 bulan di periode sebelumnya yang telah tersimpan dalam database menggunakan metode Single Exponential Smoothing. Data penjualan herbisida 36 periode akan dijadikan sampel peramalan dengan menggunakan metode Single Exponential Smoothing. Setelah datadata tersebut dimasukkan melalui halaman data penjualan dan kemudian melakukan peramalan dihalaman peramalan maka sistem akan memproses 
INDEXIA: Informatic and Computational Intelegent Journal

M. Syaichuddin, Soffiana Agustin, UmiChotijah

Peramalan Kuantiti Penjualan Herbisida Menggunakan Metode Single Exponential Smoothing Studi

Kasus Pt. Petrokimia Kayaku

dan akan menampilkan peramalan penjualan produk herbisida diperiode berikutnya dihalaman tersebut. Setelah itu untuk perbandingan dari data aktual penjualan herbisida dengan data hasil peramalan dilihat dalam grafik didalam halaman grafik akan ditunjukan perbandingan dari data aktual penjualan herbisida dan data hasil peramalan penjualan herbisida dengan 9 nilai alpha yang nantinya akan dipilih 1 hasil peramalan dengan nilai alpha terbaik.

\section{ANALISA HASIL PENGUJIAN}

Untuk analisa hasil pengujian sistem penulis menggunakan data aktual kuantiti penjualan herbisida pada PT. Petrokimia Kayaku selama 36 bulan. Didalam pengujian sistem menggunakan 3 data acuan peramalan yaitu dengan data acuan 3 bulan, 6 bulan, dan 12 bulan. Data acuan yang digunakan mulai dari bulan Januari 2015 - Desember 2017. Pada pengujian ini dilakukan pengujian dengan meramalkan penjualan produk herbisida BSM 486SL 1 Liter menggunakan data acuan 3 bulan, mulai bulan Januari 2015 - Desember 2017 untuk menentukan peramalan bulan April 2015 dengan besaran nilai alpha mulai 0,1 sampai 0,9 untuk mengetahui hasil peramalan manakah yang terbaik dengan memperoleh nilai kesalahan peramalan Mean Absolut Error (MAPE) terkecil.

Tabel 4.1 Hasil Peramalan Dengan Data Acuan 3

Bulan Alpha 0,1 - 0,9 Per Unit

\begin{tabular}{|c|c|c|c|c|c|}
\hline No & Nama Produk & Periode & Alpha & MAPE & $\begin{array}{c}\text { Hasil } \\
\text { Peramalan }\end{array}$ \\
\hline 1 & BSM 486SL 1 L & Apr 2015 & 0,1 & $8,965 \%$ & 204720,40 \\
\hline 2 & BSM 486SL 1 L & Apr 2015 & 0,2 & $9,316 \%$ & 203541,60 \\
\hline 3 & BSM 486SL 1 L & Apr 2015 & 0,3 & $9,827 \%$ & 202943,60 \\
\hline 4 & BSM 486SL 1 L & Apr 2015 & 0,4 & $10,497 \%$ & 202926,40 \\
\hline 5 & BSM 486SL 1 L & Apr 2015 & 0,5 & $11,328 \%$ & 203490,00 \\
\hline 6 & BSM 486SL 1 L & Apr 2015 & 0,6 & $12,318 \%$ & 204634,40 \\
\hline 7 & BSM 486SL 1 L & Apr 2015 & 0,7 & $13,467 \%$ & 206359,60 \\
\hline 8 & BSM 486SL 1 L & Apr 2015 & 0,8 & $14,777 \%$ & 208665,60 \\
\hline 9 & BSM 486SL 1 L & Apr 2015 & 0,9 & $16,246 \%$ & 211552,40 \\
\hline
\end{tabular}

Dari tabel diatas didapatkan hasil peramalan yang mendekati dan memperoleh nilai kesalahan peramalan Mean Absolute Persentage Error (MAPE) terkecil dibesaran nilai alpha 0,1 seperti di Tabel 4.1 yang berwarna kuning. Dari tabel diatas dapat dilihat nilai hasil pengujian peramalan dan kesalahan peramalan alpha terpilih dengan MAPE terkecil sebagai berikut:

Tabel 4.2 Hasil Peramalan Dengan Data Acuan 3

Bulan Alpha 0,1 - 0,9 Per Unit

\begin{tabular}{|c|c|c|l|l|l|l|}
\hline \multirow{2}{*}{ Periode } & Qty & $(\mathbf{F t + 1 )}$ & \multirow{2}{*}{$\mathbf{X}$ - Ft } & \multirow{2}{*}{$(\mathbf{X t - F t})^{\wedge} 2$} & Absolut & $\begin{array}{c}\text { Xt- } \\
\text { Ft/Xt }\end{array}$ \\
\cline { 2 - 3 } & $\mathbf{X}$ & $\mathbf{F}$ & & & $\mathbf{X t - F t}$ & Error \\
\hline Jan-15 & 206480 & & - & & - & \\
\hline Feb-15 & 177440 & 206480,00 & & & & \\
\hline
\end{tabular}

\begin{tabular}{|c|c|c|c|c|c|c|}
\hline Mar-15 & 215020 & 203576,00 & 11444,00 & 130965136,00 & 11444 & 0,05 \\
\hline Apr-15 & 181800 & 204720,40 & 22920,40 & 525344736,20 & 22920,4 & 0,13 \\
\hline \multicolumn{4}{|c|}{ TOTAL } & 656309872,20 & 34364,4 & 0,18 \\
\hline
\end{tabular}

$\mathrm{MSE}=656309872,16 / 2$ $=328154936,08$

MAE $=34364,40 / 2$

$=17182,2$

MAPE $=(0,179298 / 2) \times 100$

$=8,965 \%$

Jadi peramalan kuantiti penjualan herbisida mengunakan data acuan 3 bulan untuk periode bulan April 2015 diperkirakan 204720,4 dengan nilai MSE 328154936,08, MAE 17182,2 dan MAPE 8,965\%.

\section{PENUTUP}

\subsection{Kesimpulan}

Dari hasil penelitian pada peramalan kuantiti penjualan menggunakan metode Singgle Exponential Smoothing studi kasus PT. Petrokimia Kayaku, maka penulis dapat mengambil kesimpulan :

1. Metode Single Exponential Smoothing ini dapat diimplementasikan untuk studi kasus peramalan kuantiti penjualan herbisida pada PT. Petrokimia Kayaku.

2. Sistem ini mempunyai beberapa variasi perhitungan peramalan diantaranya dengan data acuan 3 Bulan, 6 Bulan, 12 Bulan, 24 Bulan, 36 Bulan dan juga dengan menggunakan perhitungan 9 alpha yang berbeda mulai dari alpha 0.1 sampai alpha 0.9 .

3. Pada tahap uji sampel dapat diketahui bahwa metode Single Exponential Smoothing perlu melakukan perbandingan dalam menentukan nilai alpha, dengan mencari nilai alpha tersebut secara acak sampai menemukan alpha yang memiliki error MAPE yang minimum. Maka hasil peramalan yang memiliki alpha dengan nilai error MAPE paling minimumlah yang paling baik.

\subsection{Saran}

Hasil penerapan metode Single Exponential Smoothing untuk meramalkan kuantiti penjualan herbisida pada PT. Petrokimia Kayaku memiliki saran untuk pengembangan penelitian di masa mendatang adalah sebagai berikut : 
INDEXIA: Informatic and Computational Intelegent Journal

M. Syaichuddin, Soffiana Agustin, UmiChotijah

Peramalan Kuantiti Penjualan Herbisida Menggunakan Metode Single Exponential Smoothing Studi

Kasus Pt. Petrokimia Kayaku

1. Menambahkan data penjualan produk herbisida lainnya untuk dapat mengetahui pergerakan penjualan pada setiap periode

2. Diharapkan adanya penelitian yang lebih komplek yang bisa digunakan untuk peramalan dengan berberapa faktor diantaranya faktor trend, faktor siklis, variasi musiman dan faktor random.

3. Menggabungkan metode peramalan kualitatif dan kuantitatif sehingga dapat memperkuat hasil peramalan.

\section{DAFTAR PUSTAKA}

Assauri, S. (1984). Teknik \& Metode Peramalan : Penerapannya Dalam Ekonomi \& Dunia Usaha. Jakarta, Jakarta: Fakultas Ekonomi Universitas Indonesia.

Dad R. J., S. (2010). Gulma dan Pengelolaannya. Yogyakarta: Graha Ilmu.

Djojosumarto, P. (2008). Pestisida dan Aplikasinya. Jakarta: Agromedia Pustaka.

Febrian, J., \& Andayani, F. (2007). Kamus Komputer dan Istilah Teknologi Informasi. Bandung: Informatika.

Gasperz, V. (2005). Production Planning and Inventory Control. Jakarta: PT. Gramedia Pustaka Utama.

Hendrayudi. (2009). VB 2008 untuk Berbagai Keperluan Pemrograman. Jakarta: Elex Media Computindo.

Kardinan, A. (2000). Pestisida nabati, Ramuan dan Aplikasi. Jakarta: Penebar Swadaya.

Makridakis, S., Wheelwright, S., \& McGee. (1983). Forecasting: Methods and Applications. New York: Wiley.

Marom, C. (2002). Sistem Akuntansi Perusahaan Dagang. Jakarta: Grasindo.

Murahartawaty. (2009). Peramalan. Bandung: Sekolah Tinggi Teknologi Telkom.

Simamora, H. (2000). Basis Pengambilan Keputusan Bisnis. Jakarta: Salemba Empat.

Subagyo, P. (2002). Forecasting Konsep dan Aplikasi. Jakarta: BPFE. 